\title{
PEMETAAN KEMAMPUAN PEMBUKTIAN MATEMATIS SEBAGAI PRASYARAT MATA KULIAH ANALISIS RIIL MAHASISWA PENDIDIKAN MATEMATIKA
}

\author{
Krisna S. Perbowo ${ }^{1}$, Trisna R. Pradipta ${ }^{2}$ \\ Universitas Muhammadiyah Prof. DR. HAMKA \\ ${ }^{1}$ krisna_satrio@uhamka.ac.id \\ 2troymath@uhamka.ac.id
}

\begin{abstract}
ABSTRAK
Masalah tentang kemampuan pembuktian matematis telah banyak dikaji oleh para ahli pendidikan matematika baik di dalam maupun di luar negeri. Studi pendahuluan ini untuk memetakan kemampuan pembuktian matematis mahasiswa yang sangat berperan penting dalam mempelajari mata kuliah analisis riil dan menganalisis learning obstacle yang dihadapi. Penelitian ini menggunakan pendekatan kualitatif yang lebih menekankan pada kajian interpretative namun dalam hal tertentu akan disajikan secara deskriptif kuantitatif. Data penelitian ini diperoleh melalui tes diagnostik terkait pembuktian matematis bentuk langsung, contrapositive, tidak langsung/ kontradiksi, dan counterexample. Subjek penelitian ini merupakan mahasiswa yang mengikuti mata kuliah analisis riil yang dipilih secara purposive sampling. Hasil penelitian ini menunjukkan bahwa: (1) kebanyakan mahasiswa tidak ingat tentang bentuk-bentuk pembuktian; (2) mahasiswa tidak mampu membuat pembuktian matematika bentuk kontrapositif dan kontradiksi; dan (3) dominan mahasiswa tidak mampu mengaplikasikan pembuktian bentuk counterexample. Salah satu faktor penyebab rendahnya kemampuan pembuktian matematis mahasiswa tersebut menurut hasil wawancara dengan mahasiswa, bahwa mereka lupa dan belum terbiasa dalam membuat pembuktian matematika dan belum banyak memahami tentang pembuktian matematika.
\end{abstract}

Kata Kunci : Pembuktian Matematis, Learning Obstacle, Kemampuan Pembuktian Matematis, Analisis Riil.

\section{PENDAHULUAN}

Pendidikan merupakan salah satu elemen penting dalam kemajuan suatu bangsa. Bangsa yang ingin maju haruslah memajukan pendidikannya terlebih dahulu. Karena melalui pendidikan, individu dapat memperoleh ilmu, pengetahuan, dan keterampilan guna meningkatkan kemampuan berpikir, berusaha, dan penguasaan teknologi. Sehingga diharapkan individu tersebut dapat memenuhi segala kebutuhan dengan segala keterampilan yang dimiliki. Salah satu upaya untuk memajukan pendidikan adalah dengan mempersiapkan tenaga-tenaga pendidik atau calon guru yang handal dan professional, karena fungsi guru menurut Undang-Undang No. 14 Tahun 2005 tentang Guru dan Dosen adalah untuk meningkatkan mutu pendidikan nasional. 
Selain keterampilan mengajar, keterampilan berpikir rasional dan terstruktur sangat dibutuhkan terutama bagi calon guru matematika. Salah satu mata kuliah yang melatih mahasiswa pendidikan matematika untuk berpikir rasional deduktif dan sistematis adalah mata kuliah analisis riil (Mutaqin, 2010). Mata kuliah analisis riil diberikan pada mahasiswa semester VI yang telah memenuhi mata kuliah prasyarat diantaranya Pengantar Dasar Matematika dan Kalkulus Peubah Banyak.

Mata kuliah analisis riil termasuk dalam kategori mata kuliah yang dinilai sangat sulit bagi mahasiswa pendidikan matematika (Darmadi, 2011; Mutaqin, 2010). Salah satunya dikarenakan Analisis Riil banyak membahas pembuktian-pembuktian teorema yang sangat memerlukan berpikir analitis yang tinggi (Bartle, 1975). Sedangkan selama perkuliahan mahasiswa tidak banyak bersinggungan dengan proses analisis teorema atau pembangunan argumen menggunakan teorema yang ada di dalam matematika.

Matematika di tingkat perguruan tinggi menuntut mahasiswa calon guru matematika agar mencapai tahap mathematical maturity (kedewasaan matematis). Di tahap ini mahasiswa tidak lagi hanya mendalami pemecahan masalah yang telah diketahui metode dan algoritmanya, namun lebih kepada menulis pembuktian dan menghasilkan counterexample yang melibatkan objek dan konsep yang abstrak, serta melakukan aktivitas matematis dengan algoritma yang tidak didefinisikan (Kurtz, 1992).

Dengan melihat perkembangan pembelajaran Analisis Riil dan berbagai kesulitan yang muncul dari diri mahasiswa, maka peneliti merasa perlu untuk memetakan kemampuan pembuktian matematis yang sangat berperan penting dalam mempelajari subjek Analisis Riil.

\section{KAJIAN TEORI}

\section{Analisis Riil}

Menganalisis sistem bilangan riil maknanya adalah untuk memahami bagianbagian, himpunan, barisan, fungsi, dan hubungan antarbagian bilangan riil sehingga diperoleh pengertian dan sifat-sifat secara tepat dan menyeluruh (Darmadi, 2011; Bartle \& Sherbert, 2011). Subjek matematika yang secara khusus membahas tentang analisis terkait system bilangan riil adalah analisis riil.

Analisis riil merupakan salah satu subjek yang dipelajari oleh mahasiswa matematika murni atau matematika terapan maupun pendidikan matematika di perguruan tinggi. Tujuan dari mempelajari adalah untuk mengembangkan kemampuan berpikir 
deduktif, kemampuan analisis situasi matematis, dan mengembangkan ide matematis dalam beragam konteks (Bartle \& Sherbert, 2011). Untuk mempelajari analisis riil diperlukan beberapa kemampuan prasyarat seperti penalaran, logika dan pembuktian matematik yang diperoleh dari mempelajari subjek pengantar dasar matematika dan kalkulus.

Dengan memperoleh pengalaman dari mempelajari analisis riil akan meningkatkan mathematical maturity (kedewasaan matematis) mahasiswa yang sangat berguna dalam proses berpikir tingkat tinggi.

\section{Kemampuan Pembuktian Matematis}

Salah satu sifat dari matematika adalah terstruktur secara deduktif aksiomatik. Kebenaran yang ada didalam matematika didasari oleh kebenaran sebelumnya yang telah disepakati. Struktur yang ada di dalam matematika diawali dengan definisi, aksioma atau postulat, dan teorema.

Teorema yang muncul harus melalui proses pembuktian matematis secara deduktif untuk memeriksa bahwa teorema berlaku secara umum pada sistemnya. Terkadang untuk menemukan sifat atau prinsip yang ada dalam matematika tidak selalu diperoleh dengan proses berpikir deduktif, namun juga diperoleh dengan proses berpikir induktif. Baik perolehannya dari hasil berpikir deduktif dan induktif, kebenarannya matematika tidak boleh hanya berasal dari asumsi umum hasil berpikir induktif. Selain kemampuan berpikir deduktif dan induktif, untuk bisa memiliki kemampuan pembuktian matematis diperlukan pemahaman dan penguasaan konsep dasar matematika yang baik (Santosa, 2013). Adapun menurut Selden \& Selden (2003) kemampuan pembuktian matematis meliputi:

1. Kemampuan menyusun pembuktian.

2. Kemampuan memvalidasi bentuk pembuktian.

\section{Learning Obstacle}

Salah satu aspek yang perlu menjadi pertimbangan bagi pengajar adalah adanya learning obstacle. Brown (2008) mendefinisikan obstacle sebagai suatu cara pemahaman (way of knowing) yang secara produktif berfungsi pada beberapa seting pembelajaran, sementara hal tersebut mendukung terbentuknya kesalahan pada cara pemahaman yang lainnya. Produktivitas atau keberhasilan ini dikatakan cara pemahaman yang mengakar bila hal tersebut sulit untuk diubah. Itulah yang dinamakan dengan obstacle. 
Obstacle memiliki tiga bentuk, yaitu: ontogenis, didaktis, dan epistemologis. Hambatan ontogenis berkaitan dengan hambatan yang muncul karena perkembangan siswa, hal ini akibat dari tingkat perkembangan anak. Hambatan didaktis adalah hambatan yang muncul sebagai akibat dari cara pengajaran dan oleh karena itu dapat dihindari melalui pengembangan pendekatan instruksional alternatif atau desain didaktis alternatif. Hambatan Epistemologis berkaitan dengan sesuatu yang timbul akibat dari pendekatan pengajaran, asal mulanya adalah dari konsep itu sendiri (yang diajarkan), dengan kata lain untuk mengatasi hambatan tersebut adalah bagian dari konstruksi kebermaknaan suatu konsep (Brown, 2008).

Learning obstacle yang bersifat epistemologis merupakan salah satu aspek yang diperlukan pengajar dalam mengembangkan Antisipasi Didaktis dan Pedagogis (ADP). Ini bukan berarti dengan memodifikasi desain didaktis (atau setting) pengajar tidak lagi membuat hambatan didaktis yang sama melainkan dengan membuat alternatif desain didaktis (atau setting), pengajar dapat mengurangi kemungkinan munculnya hambatan yang sama, selain itu hal ini juga dapat memperbesar kemungkinan proses diagnostik peserta didik (Brown, 2008).

\section{METODE PENELITIAN}

\section{Pendekatan Penelitian}

Penelitian ini membutuhkan data yang bersifat kualitatif, namun tidak tertutup kemungkinan dalam hal tertentu akan disajikan secara deskriptif kuantitatif. Dalam penelitian ini menggunakan pendekatan kualitatif, yaitu pendekatan dalam mengolah data mulai dari mereduksi, menyajikan, memverifikasi, dan menyimpulkan data, dengan tidak menggunakan perhitungan-perhitungan secara matematis dan statistik, melainkan lebih menekankan pada kajian interpretatif (Moleong, 2007).

Peneliti membuat gambaran kompleks bersifat holistik, menganlisis kata-kata, melaporkan pandangan-pandangan para informan secara rinci, dan melakukan penelitian pada suatu konteks khusus yang alamiah. Hal ini dikarenakan yang menjadi objek penelitiannya seringkali bersifat unik, kasuistis, dan tidak ada duanya. Untuk memperoleh pemahaman mendalam dari fenomena/kasus yang terjadi secara ilmiah yang berkaitan dengan kajian di atas, maka peneliti berperan sebagai instrumen utama dalam pengumpulan data dengan cara mengobservasi langsung subjek yang diteliti (Irawan, 2007); pandangan peneliti berperan sebagai instrumen untuk memahami dan menjelaskan 
situasi hambatan belajar (learning obstacle) mahasiswa pendidikan matematika FKIP dalam melakukan pembuktian matematik. Hal ini sebagaimana yang dijelaskan oleh Moleong (2007) bahwa hanya manusia sajalah yang dapat berhubungan dengan responden atau objek lainnya, dan hanya manusia sajalah yang mampu memahami kaitan kenyataankenyataan di lapangan.

\section{Teknik Pengumpulan Data}

Penelitian meliputi identifikasi kesulitan/hambatan belajar mahasiswa dan pemetaan kemampuan pembuktian matematik mahasiswa. Kesulitan-kesulitan mahasiswa pada pembuktian matematik yang diajukan dilihat dari sudut pandang karakteristik kesulitan mahasiswa. Sedangkan data kemampuan pembuktian matematik diperoleh melalui tes diagnostik terkait pembuktian matematik bentuk langsung, contrapositive, tidak langsung/kontradiksi, dan counterexample. Instrumen tes diagnostik pembuktian matematik telah melalui tahap validasi pakar agar mendapatkan instrumen yang memenuhi kriteria valid dan reliabel. Jawaban pertanyaan tes digunakan sebagai sumber data. Data yang tidak terungkap melalui tes diperdalam dengan mempergunakan wawancara (Moleong, 2007) dan kajian kepustakaan (Irawan, 2007).

\section{Subjek Penelitian dan Sumber Data}

Subjek penelitian ini merupakan mahasiswa pendidikan matematika semester VI yang mengikuti mata kuliah Analisis Riil tahun ajaran 2015/2016. Sumber data yang dipergunakan untuk kepentingan analisis dalam penelitian ini dibagi dalam dua kategori, yaitu: 1) hasil tes responden terkait pembuktian matematik, 2) sumber responden, dipilih secara purposive sampling, yang didasarkan pada kriteria: memiliki peran penting pembelajaran analisis riil, memiliki pengetahuan berharga sesuai dengan kajian penelitian, dan memiliki keinginan bekerja sama serta berbagi informasi tentang kajian penelitian.

\section{Teknik Analisis Data}

Data yang terkumpul dalam penelitian ini berupa data verbal. Analisis data menggunakan model interaktif dari Milles dan Hubarmen (Supriatna, 2011), analisis data dilakukan mengikuti tahap-tahap berikut: 
1. Pengumpulan data

Pada tahap ini data kesulitan-kesulitan responden terkait pembuktian matematis diperoleh dari hasil tes, data yang tidak terungkap melalui tes diperdalam dengan menggunakan teknik wawancara dan dokumentasi.

2. Reduksi data

Data yang diperoleh di lapangan selanjutnya dipilih sesuai dengan tujuan permasalahan yang ingin dicapai. Dari hasil kegiatan mereduksi data ini, data terpilih kemudian dipisahkan dari data yang tidak perlu. Akan tetapi, data tersebut tidak dihilangkan. Maksudnya, data lain yang terungkap lewat pengambilan data tetap dipertimbangkan untuk mendukung data utama. Selanjutnya, data setiap aspek diteliti.

3. Penyajian data

Dalam tahap ini, data akan disajikan secara kuantitatif deskriptif yaitu dalam bentuk tabel dan presentase, adapun aspek-aspek yang diteliti sesuai identifikasi penelitian.

4. Penarikan kesimpulan

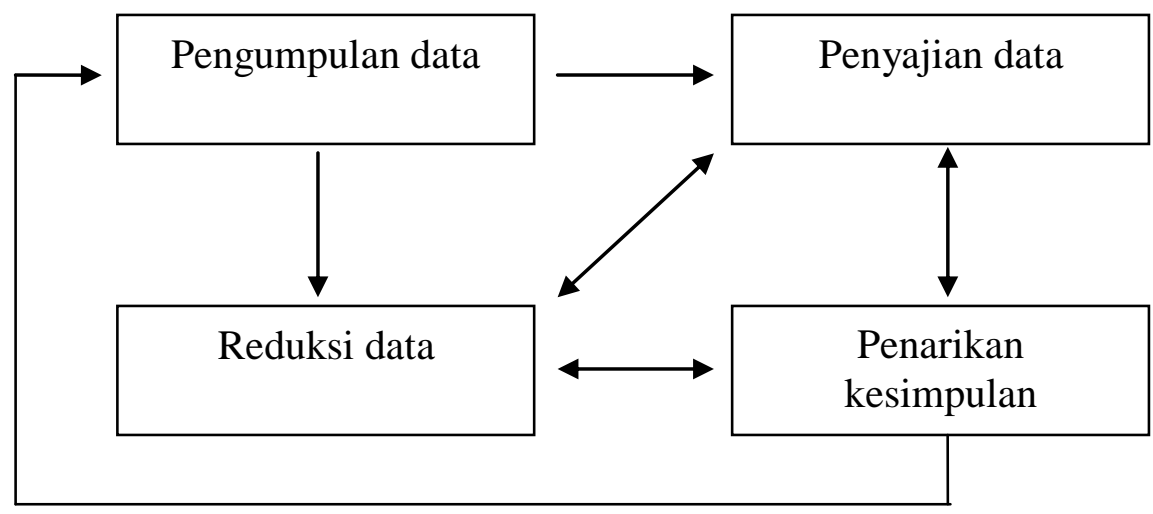

Gambar 1. Komponen-komponen Analisis Data

Dari gambar 1 menunjukan bahwa penarikan kesimpulan diperoleh setelah kegiatan mereduksi data dan menyajikan data. Kesimpulan merupakan hasil kegiatan mengaitkan pertanyaan-pertanyaan penelitian dengan data yang diperoleh di lapangan.

Setelah data terkumpul, analisis akan dilakukan dengan cara induktif, mendekatkan data temuan pada teori landasan, sebagaimana yang dijabarkan oleh Miles dan Huberman (Supriatna, 2011) langkah-langkah dan analisisnya adalah sebagai berikut:

1. Mengidentifikasi kesulitan-kesulitan mahasiswa (learning obstacles) pada pembuktian matematik.

2. Mengidentifikasi kemampuan pembuktian matematis mahasiswa.

3. Menarik kesimpulan. 


\section{HASIL PENELITIAN DAN PEMBAHASAN}

Kemampuan mahasiswa dalam melakukan pembuktian matematik meliputi, pembuktian langsung bentuk implikasi, pembuktian contrapositive, pembuktian tidak langsung berupa bentuk reductio ad absurdum atau kontradiksi.

Mahasiswa diberikan dua masalah berupa teorema yang berbeda. Masalah pertama, mahasiswa melakukan 3 macam pembuktian dari sebuah teorema seperti berikut.

Teorema:

"Jika $x$ dan $y$ bilangan genap, maka $x+y$ merupakan bilangan genap"

Untuk jenis pembuktian langsung diperoleh sebagaimana gambar 2 berikut.

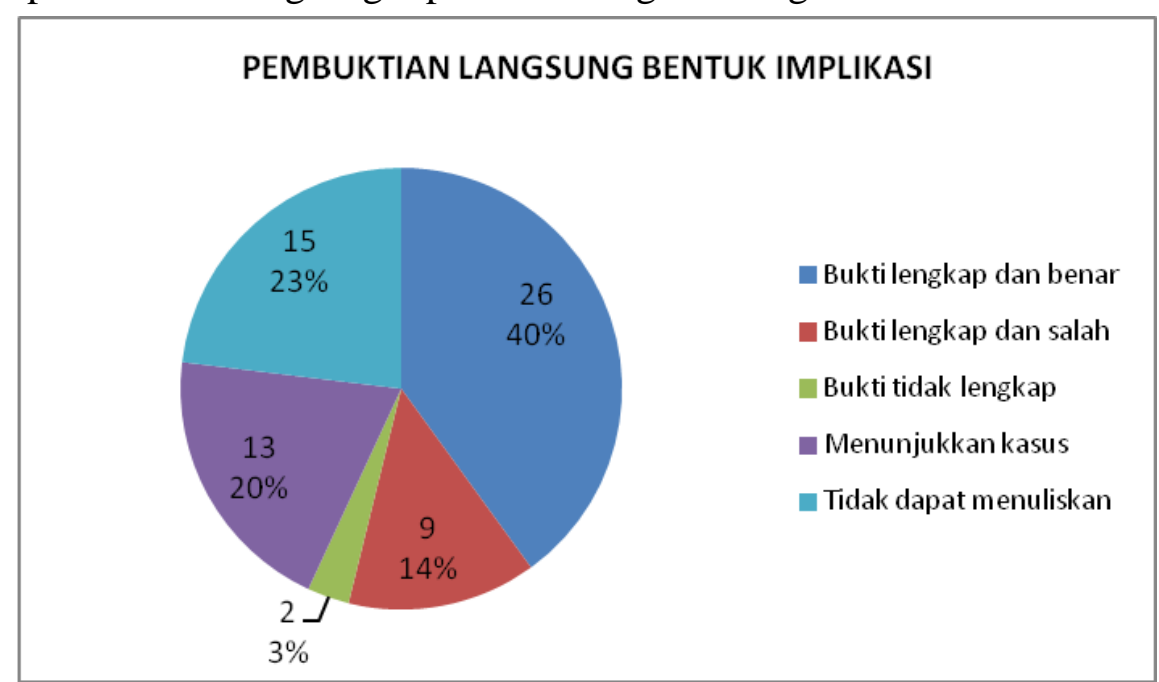

Gambar 2. Persentase Kemampuan Pembuktian Bentuk Implikasi Mahasiswa

Berdasarkan gambar 2 diketahui dominan mahasiswa yaitu $40 \%$ mampu memberikan bukti yang lengkap dan benar, sedangkan hanya $3 \%$ yang memberikan bukti tidak lengkap sehingga pembuktian tercapai.

Untuk jenis pembuktian bentuk kontrapositif diperoleh sebagaimana gambar 3 berikut.

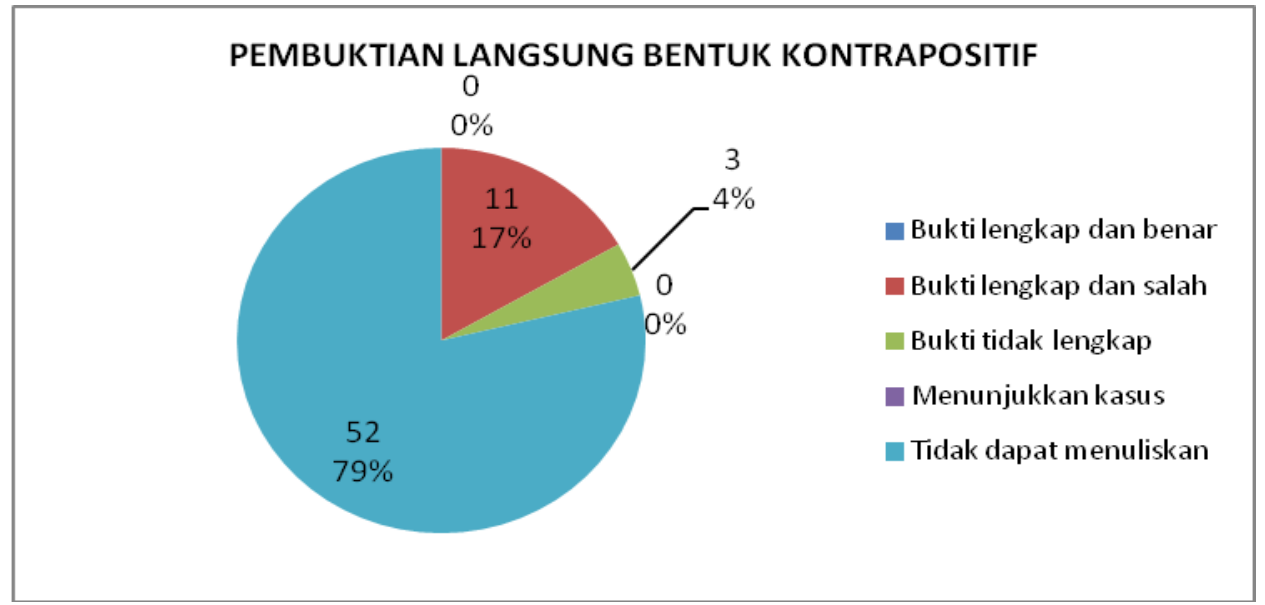

Gambar 3. Persentase Kemampuan Pembuktian Bentuk Kontrapositif Mahasiswa 
Dominan mahasiswa yaitu $79 \%$ tidak mampu menuliskan pembuktian teorema sama sekali, dan tidak ada mahasiswa yang dapat memberikan bukti teorema menggunakan bentuk kontrapositif.

Untuk jenis pembuktian bentuk kontradiksi diperoleh sebagaimana gambar 4 berikut.

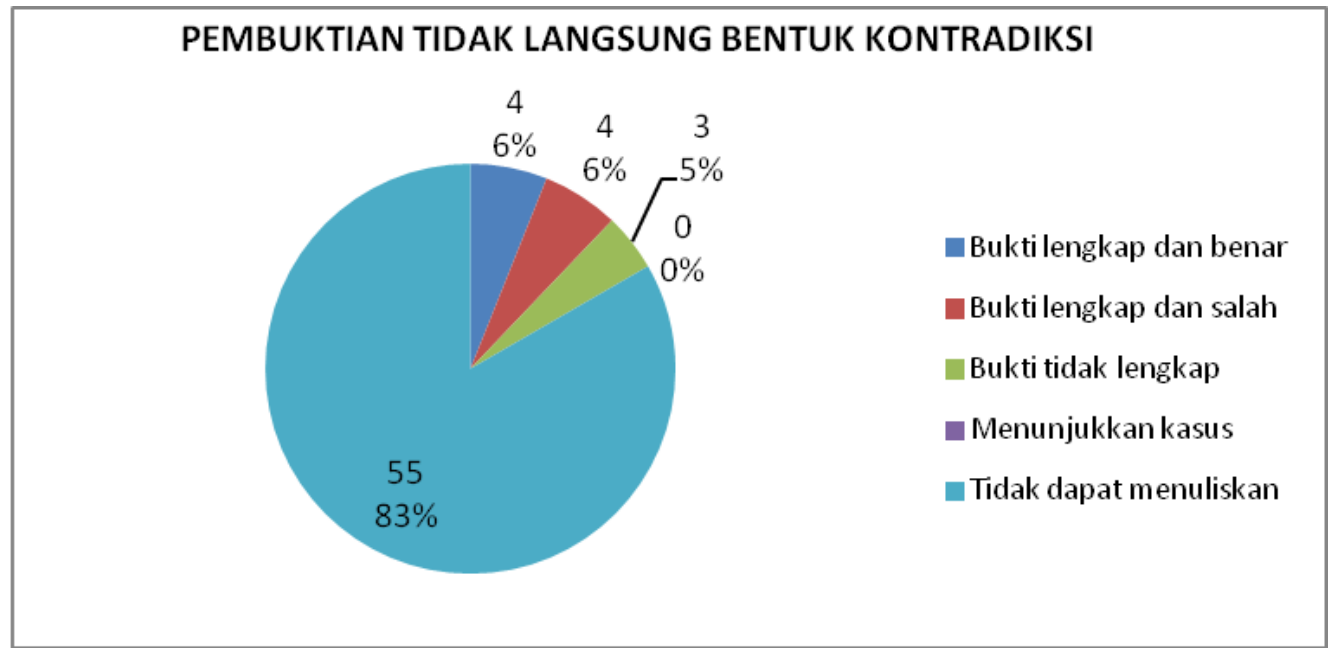

Gambar 4. Persentase Kemampuan Pembuktian Bentuk Implikasi Mahasiswa

Dominan mahasiswa yaitu $83 \%$ tidak mampu menuliskan pembuktian teorema sama sekali, sedangkan hanya $6 \%$ mahasiswa yang dapat memberikan bukti secara lengkap dan benar.

Terkait bentuk pembuktian counterexample di sini tidak muncul dikarenakan penggunaan bentuk pembuktian counterexample digunakan pada premis/teorema yang bernilai salah.

Dari hasil pengujian kemampuan matematik berdasarkan dua bentuk masalah, yaitu memberikan bukti matematik dan validasi bentuk pembuktian terlihat kemampuan mahasiswa dalam melakukan pembuktian matematik yang meliputi, pembuktian langsung bentuk implikasi, pembuktian contrapositive, pembuktian tidak langsung berupa bentuk reductio ad absurdum atau kontradiksi masih sangat rendah.

Bentuk pembuktian yang paling sulit dilakukan oleh mahasiswa adalah bentuk kontrapositif dan kontradiksi, hal ini terlihat dari tidak mahasiswa yang mampu memberikan pembuktian bentuk kontrapositif sama sekali, sedangkan hanya 6\% mahasiswa yang mampu memberikan bentuk pembuktian kontradiksi. 
Di lain pihak, mahasiswa terlihat lebih mudah untuk melakukan pembuktian langsung bentuk implikasi. Sebagaimana data menunjukkan sebanyak $40 \%$ mahasiswa yang mampu menyajikan bentuk pembuktian langsung secara lengkap dan benar.

Kemudian, ketika mahasiswa diuji untuk memvalidasi dan membedakan bentuk pembuktian, diperoleh rendahnya pemahaman mahasiswa terkait bentuk pembuktian matematik. Hal ini terlihat dari 10 item yang diujikan paling banyak hanya 6 mahasiswa (18\%) yang mampu memvalidasi dan membedakan bentuk pembuktian.

Indikasi kesukaran dalam kemampuan pembuktian ini sejalan dengan yang dinyatakan oleh Kurtz (1992), "a major part of the difficulty (dalam melakukan pembuktian-pen) seems to be due to an imprecise knowledge of the fundamentals of mathematics; logic, sets, relations, and functions". Kurangnya penguasaan materi prasyarat sangat mempengaruhi penguasaan mahasiswa dalam pembuktian matematik.

\section{KESIMPULAN}

Berdasarkan hasil penelitian dan pembahasan di atas, dapat dikemukakan beberapa kesimpulan sebagai berikut:

1. Dominan mahasiswa yang tidak bisa menjawab karena lupa atau tidak ingat tentang bentuk pembuktian, padahal pada beberapa mata kuliah, mahasiswa melakukan pembuktian matematik.

2. Mahasiswa tidak mampu membuat pembuktian matematis bentuk kontrapositif.

3. Kebanyakan mahasiswa tidak mampu membuat pembuktian matematika bentuk kontradiksi.

4. Mahasiswa tidak mampu mengaplikasikan pembuktian bentuk counterexample dikarenakan mahasiswa menganggap counterexample hanya digunakan pada premis yang bernilai salah.

\section{REKOMENDASI}

1. Perlunya perhatian lebih ketika mengenalkan pembuktian matematik (dalam hal ini terutama pada mata kuliah Pengantar Dasar Matematika).

2. Perlunya penelitian yang menganalisis lebih lanjut terkait obstacle (hambatan) dalam mempelajari pembuktian matematis.

3. Para dosen perlu bersinergi dalam memberikan penguatan dan pengingat terhadap bentuk pembuktian yang digunakan dalam pembelajaran mata kuliah yang diampu. 


\section{REFERENSI}

Bartle, R.G. \& Sherbert, D.R. (2011). Introduction to Real Analysis $-4^{\text {th }}$ Edition. Illinois: John Wiley \& Sons.

Bartle. R.G. (1975). The Elements of Real Analysis. Second Edition. New York: John Wiley \& Sons.

Brown, S.A. (2008). Exploring Epistemological Obstacle To The Development of Mathematics Induction. Proceeding of The $11^{\text {th }}$ Conference For Research on Undergraduate Mathematics Education. San Diego.

Darmadi. (2011). Prosiding dari Seminar Nasional Matematika dan Pendidikan Matematika: Matematika dan Pendidikan Karakter dalam Pembelajaran. Yogyakarta: Jurusan Pendidikan Matematika FMIPA UNY.

Irawan, P. (2007). Penelitian Kualitatif \& Kuantitatif Untuk Ilmu-Ilmu Sosial. Depok: DIA FISIP UI.

Kurtz, D.C. (1992). Foundations of Abstract Mathematics. Singapore: McGraw-Hill.

Moleong, L.J. (2007). Metodologi Penelitian Kualitatif. Bandung: Rosda.

Mutaqin, A. (2010). Mengapa Harus Belajar Analisis Real. Diperoleh dari https://anwarmutaqin.wordpress.com/2010/03/05/mengapa-harus-belajar-analisisreal/ (2016, 25 April).

Santosa, C.A.H.F. (2013). Mengatasi Kesulitan Mahasiswa Ketika Melakukan Pembuktian Matematis Formal. Jurnal Pengajaran MIPA, 18(2), 152-160.

Selden, A \& Selden, J. (2003). Validations of Proofs Considered as Texts: Can Graduates Tell Whether an Argument Proves a Theorem?. Journal for Research in Mathematics Education, 34(1), 4-36.

Supriatna, T. (2011). Pengembangan Desain Didaktis Bahan Ajar Pemecahan Masalah Matematis Luas Daerah Segitiga Pada Sekolah Menengah Pertama. Tesis SPs. UPI. Bandung: Tidak Diterbitkan.

Undang-Undang No. 14 Tahun 2005 Tentang Guru dan Dosen. 